\title{
Dietary fibres - important parts of high quality food and feeds*
}

\section{Charlotte Bjergegaard, H. Sørensen and Susanne Sørensen}

\author{
Chemistry Department, Royal Veterinary and Agricultural University \\ 40. Thorvaldsensvej, DK-187I Frederiksberg C, Denmark
}

(Received 25 April 1997; accepted 15 May 1997)

\begin{abstract}
Dietary fibres (DF) are mainly plant cell wall constituents or plant materials resistant to hydrolysis catalysed by enzymes secreted from mammalian cells in the first part of the mammalian digestive tract. Our interest in DF is directed at physiological effects caused by DF; their effects on nutrients and non-nutrients including xenobiotics, and effects on the structure and composition of digesta including the microflora in the digestive tract. This means that DF have several both positive and negative effects on the quality of food and feed depending on the type of DF, and as DF are a necessary or important part of all high quality foods and feeds, focus should be placed on obtaining more exact structural information on $\mathrm{DF}$.

The chemical composition and structure of DF, their physico-chemical properties and physiological cffects comprise thereforc an area of increasing interest. In consequence thereof, we have placed specific focus on all parts of DF, not only the carbohydrates, but all DF constituents which give a contribution to the binding properties of DF toward nutrients and non-nutrients. These studies of DF have required investigations based on isolated DF, and it is found, that the unsolved problems, which also require a solution, are the questions of possible differences in effects in food/feed matrixes of isolated DF and indigenous DF. However, the research needs in all cases to be focused on the information required with respect to structure and properties of DF. Such investigations must be based on analytical methods, and the level of information obtainable therefrom can, as other systematic biochemical-natural product chemical research studies, be divided into 4 levels denoted as the $4 \times \mathrm{C}$ : 1 . Composition: types of carbohydrates, lipids, proteins, phenolics and other compounds in DF; 2. Constitution: structure of the DF compounds and DF itself 3 . Configuration: stereochemistry of DF/DF components: 4 . Conformation: the actual or preferred spatial structure of the solvated DF.
\end{abstract}

* Part of this paper was presented at the Symposium: Dictary fibre - chemical composition and biological action, 24-25 April 1997, Radzików, Poland 
In systematic DF studies of this type, the sequence needs to be from information level 1 to level 4 , and the last three levels of information are important for an understanding of the binding properties or physiological effects DF may have.

KEY WORDS: dietary fibres

\section{INTRODUCTION}

Dietary fibres (DF) vary in structure and properties depending on the DF source; plant family, genera, variety, plant part, growth conditions, development of the plant and the applied processing of food and feed (Bjergegaard et al., 1991a,b; Bjergegaard and Sørensen, 1992). DF from cereals vary thus from legume- and cruciferous DF, and the type, structure and properties of DF from young unripe plant parts are different from DF in corresponding parts of old and mature plants. The ability of DF to create the wanted structure of digesta as basis for an optimal microflora and the ability to bind both nutrients and nonnutrients (Arentoft and Sørensen, 1992), xenobiotics, toxic or antinutritional compounds (ANC) are thus a function of the type of DF (Bjergegaard and Sørensen, 1996). The binding of nutrients can both be micronutrients and macronutrients as proteins, lipids and starch, reducing the digestibility of protein (TD) and energy (DE), which are important factors in discussions of feed quality (Danielsen et al., 1994). The binding of micronutrients as vitamins, essential nutrients and minerals (Bjergegaard et al., 1991b; 1994) as well as non-nutrients, xenobiotics or ANC (Bjergegaard and Sørensen, 1996), can affect the biological value of e.g. proteins (BV), and thereby also the quality of both feed and food. Excellent contributions in the area of DF research illustrating the great number of different reasons to focus on DF and the various points of views that different researcher groups have on DF are described in proceedings of meetings concentrating on DF (Furda and Brine, 1990; Waldron et al., 1993; COST 92, 1995).

\section{PLANT CELL WALLS AND CONSTITUENTS OF DIETARY FIBRES}

Plant cell walls are the quantitatively dominating part of DF, but the undigested part of plant foods may also contain starch, often denoted resistant starch. Based on the analytical method of DF determination, this fraction can be divided into insoluble dietary fibres (IDF) and soluble dietary fibres (SDF). Further separation of DF can be obtained by sequential extraction of DF in water, alkaline solution and sulphuric acid resulting in; pectins, hemicelluloses, cellulose and lignin (Bjergegaard et al., 1997). Each of these fractions are composed of heterogenous groups of compounds (Figure 1; Table 1), varying 


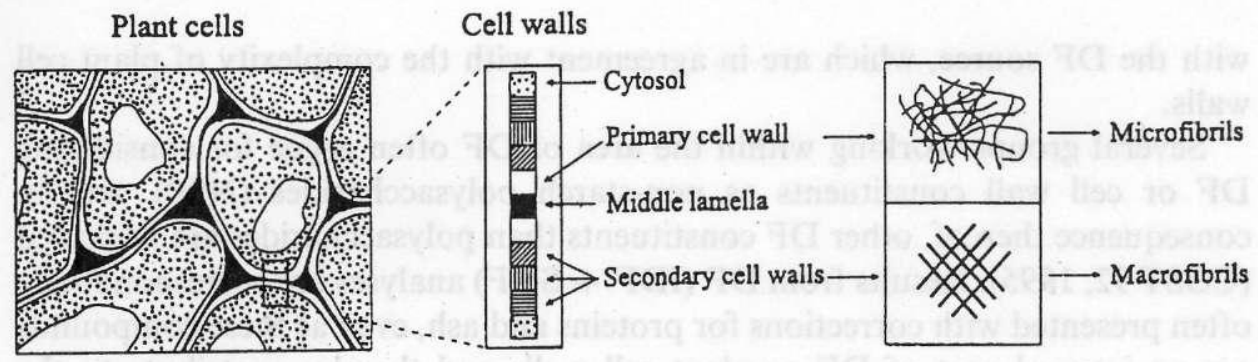

Microfibril
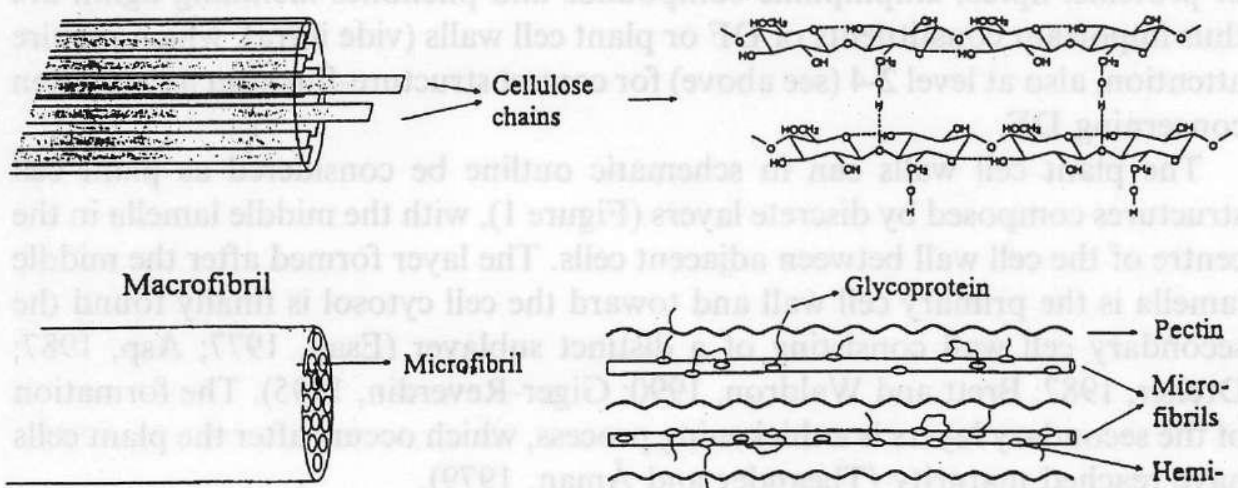

Figure 1. Schematic outline of plant cell walls and illustration of the arrangement of some cell wall structures and compounds involved in the structural arrangement

TABLE 1

Quantitatively important constituents of the matrix in plant cell walls

\begin{tabular}{|c|c|c|c|}
\hline \multicolumn{4}{|c|}{ Matrix } \\
\hline Pectins & Hemicelluloses & Proteins & Phenolics \\
\hline Arabinans & Xylans & $\begin{array}{l}\text { Glycoproteins } \\
\text { including }\end{array}$ & Lignins \\
\hline Galactans & Xyloglucans & $\begin{array}{l}\text { Arabinogalactan- } \\
\text { proteins (AGPs) }\end{array}$ & Sinapic acid \\
\hline Arabinogalactans & Galactomannans & Extensine & Ferulic acid \\
\hline Galactouronans & Glucomannans & $\begin{array}{l}\text { Hydroxyproline rich } \\
\text { glycoproteins (HRGPs) }\end{array}$ & Coumaric acid \\
\hline Homogalactouronans & Mannans & $\begin{array}{l}\text { Glycine rich } \\
\text { proteins (GRP) }\end{array}$ & $\begin{array}{l}\text { Ofter with the acids } \\
\text { covalently attached }\end{array}$ \\
\hline $\begin{array}{l}\text { Rhamnogalacto- } \\
\text { uronans I,II }\end{array}$ & Galoctoglycomannans & $\begin{array}{l}\text { Proline rich proteins } \\
\text { (PRPs) }\end{array}$ & $\begin{array}{l}\text { to the carbohydrates } \\
\text { by ester bonds and also }\end{array}$ \\
\hline (Oligosaccharides) & Arabinogalactan II & Enzymes & $\begin{array}{l}\text { as dimers (lignans) } \\
\text { forming cross links in the } \\
\text { polysaccharides }\end{array}$ \\
\hline
\end{tabular}


with the DF source, which are in agreement with the complexity of plant cell walls.

Several groups working within the area of DF often argue for considering DF or cell wall constituents as non-starch polysaccharides (NSP), and in consequence thercof, other DF constituents than polysaccharides are neglected (COST 92, 1995). Results from DF (IDF + SDF) analyses are correspondingly often presented with corrections for proteins and ash, even as these compounds are an integral part of DF or plant cell walls and thereby contribute to the structure and important properties of DF (Furda and Brine, 1990). Various types of proteins, lipids, amphiphilic compounds and phenolics including lignin are thus important constituents of DF or plant cell walls (vide infra), which require attention, also at level 2-4 (see above) for correct structure-function information concerning DF.

The plant cell walls can in schematic outline be considered as plant cell structures composed by discrete layers (Figure 1), with the middle lamella in the centre of the cell wall between adjacent cells. The layer formed after the middle lamella is the primary cell wall and toward the cell cytosol is finally found the secondary cell wall consisting of a distinct sublayer (Esau, 1977; Asp, 1987; Dreher, 1987; Brett and Waldron, 1990; Giger-Reverdin, 1995). The formation of the secondary layers is a thickening process, which occurs after the plant cells have reached maturity (Theander and Åman, 1979).

The unique features that plant cell walls possess compared to animal cell walls or membranes are their strength and rigidity protecting the individual cells from osmotic rupture and mechanical injury. The plant cell walls are also one of the major factors that cause plant based food and feed to differ so much from food of animal origin. In addition, the plant cell walls are dynamic structures that carry out many biochemical activities including transport of biomolecules, as is also the case for animal cell walls. This means that the plant cell walls contain several proteins and associated enzymes, which can degrade nutrients and non-nutrients as e.g. myrosinase catalysed glucosinolate hydrolysis found for cruciferous/rapeseed products (Michaeisen et al., 1994; Bjergegaard and Sørensen, 1995).

\section{TYPE AND STRUCTURE OF CELL WALL OR DF CONSTITUENTS}

Plant cell walls or DF are composed of a complex group of high molecular weight (HMW) compounds that are secreted by and surround the cells (Figure 1). The quantitatively dominating compounds are polysaccharides, especially cellulose. 


\section{Cellulose}

Cellulose is a linear polymer of glucopyranose units linked together through $\beta(1,4)$ bonds (Figure 2).

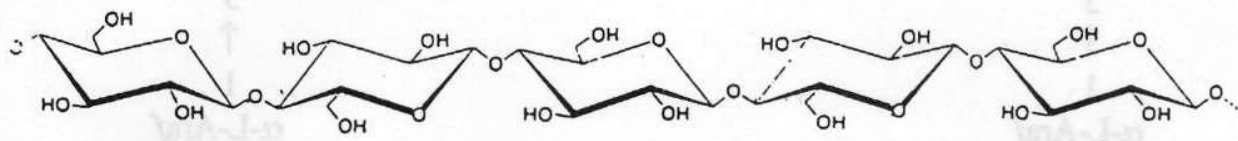

Figure 2. Fragment of cellulose chain illustrating the linear structure resulting from $\beta(1,4)$ linked D-glucopyranose units

The linear structure of cellulose gives the basis for hydrogen bonds as shown in Figure 1. The individual cellulose molecules of $\mathrm{MW}>50 \mathrm{kD}$ interact in parallel bundles of 50-60 cellulose molecules that line up in parallel and adhere to one another, forming long, rigid microfibrils (Figure 1). These microfibrils are often twisted together in a ropelike fashion to generate macrofibrils. These special structural features of cellulose result in molecules which are nearly insoluble in water, and for analytical purposes concentrated sulphfuric acid is used initially as solvent for cellulose (Bjergegaard et al., 1997). Cellulose in the cell wall is, however, more than a collection of fibrils, as it is associated with several other types of biomolecules as pectins, hemicelluloses, proteins, glycoproteins, lignins and other phenolics (Figure 1), forming the matrix.

The plant cell walls contain thus a great number of different compounds in each of four major matrix categories (Table 1), but all of the matrix constituents will not occur in all types of cell walls or DF.

\section{Pectins}

This group of compounds contains most often relatively great amounts of uronic acids and derivatives thereof, especially galacturonic acid, in the glycans which thereby readily form hydrated gels. Pectins are also involved in binding adjacent cell walls together, and in forming the matrix in which microfibrils are imbedded (Figure 1). Arabinans occurring in seeds of Sinapis alba, Brassica campestris, rapeseed (Siddiqui and Wood, 1977) and soyabean (Glycine max; Aspinall and Cottrell, 1971) are highly branched, acid-sensitive polymers of $\alpha$-L-Ara $f$ units linked by $1-5$ bonds and extensively substituted at C-3 and also at C-2 (Figure 3).

Galactans are linear or slightly branched polysaccharides with a backbone of $\beta$-D-Gal $p$ units linked by 1-4 bonds (Stephen, 1983). Arabinans, galactans and Type I arabinogalactans are neutral pectins which occur in rape seed (Grenet and Besle, 1991). Type I arabinogalactans consists of a galactan backbone substituted with Ara rich branches. Type II arabinogalactans occur in rape seed and 

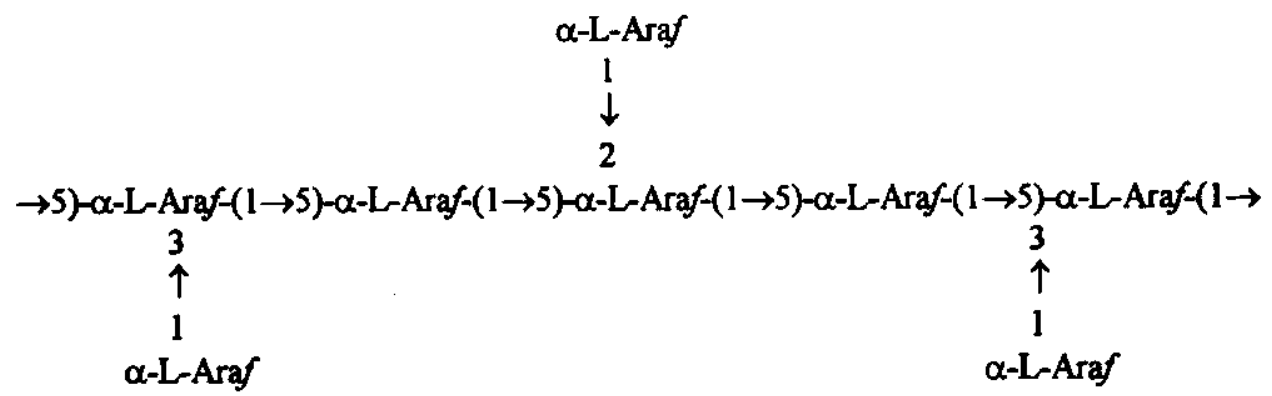

Figure 3. Fragment of arabinans which occur as part of the cruciferous pectins

constitute a diverse group of highly branched polymers rich in $\mathrm{Gal}$, and with varying amounts of Ara, Rha, GalA and GlcA, and these glycans are usually found in association with proteins (Stephen, 1983; Brett and Waldron, 1990; O'Neill et al., 1990). Galacturonans/homogalacturonans are unbranched polymers dominated by $\beta$-D-GalA $p$ units linked by $1-4$ bonds. Rhamnogalacturonans I have a backbone of the disaccharide sequence

$$
\rightarrow 4)-\alpha \text {-D-GalA } p \text { - }(1 \rightarrow 2)-\alpha \text {-L-Rhap-( } 1 \rightarrow 4)-\alpha \text {-D-GalA } p \text { - }(1 \rightarrow 2)-\alpha-L-R h a p-(1 \rightarrow
$$

About $50 \%$ of the rhamnosyl residues are substituted with oligosaccharides rich in Ara and Gal (Fry, 1988). Rhamnogalacturonans II have a backbone rich in $\alpha$-D-GalA $p$, highly branched with side groups containing Gal, GalA, Rha, Gle, GlcA, Ara, Xyl and for some cell walls with fucose and apiose. Associated to the pectins are in some cases oligosaccharides/ $\alpha$-galactosides, e.g. in DF from pea and other legume seeds (Arentoft and Sørensen, 1992).

\section{Hemicelluloses}

Hemicelluloses are separated from pectins on the basis of solubility in aqueous systems, and no sharp borderline exists between these two groups of compounds. Hemicelluloses are like pectins a heterogenous group of glycans (Table I) with appreciable variations in structure, substitution and number of branches (Moore and Hatfield, 1994), which depend on the DF source. Xylans have a backbone of $\beta$-D-Xyl $p$ units linked by $1-4$ bonds, but unsubstituted xylans are rare, and substituents are often $\alpha$-L-Araf (Figure 4), $\alpha$-D-GlcA $p$ and 4-methyl- $\alpha$-D-GlcA $p$. In dicots, xylans constitute about $5 \%$ of the primary and $20 \%$ of the secondary cell walls (Fry, 1988), and acylation with p-coumaric- and ferulic acids as well as cross-links by ferulic acid bridges seems to be part of the links between xylans and lignin (liyama et al., 1994). Arabino xylans contain often about $1 \%$ of sinapic acid, fcrulic acid and other cinnamic acids attached by esterbonds (Theander et al., 1993). In woody tissues xylans may account for as much as $50 \%$ of the cell 


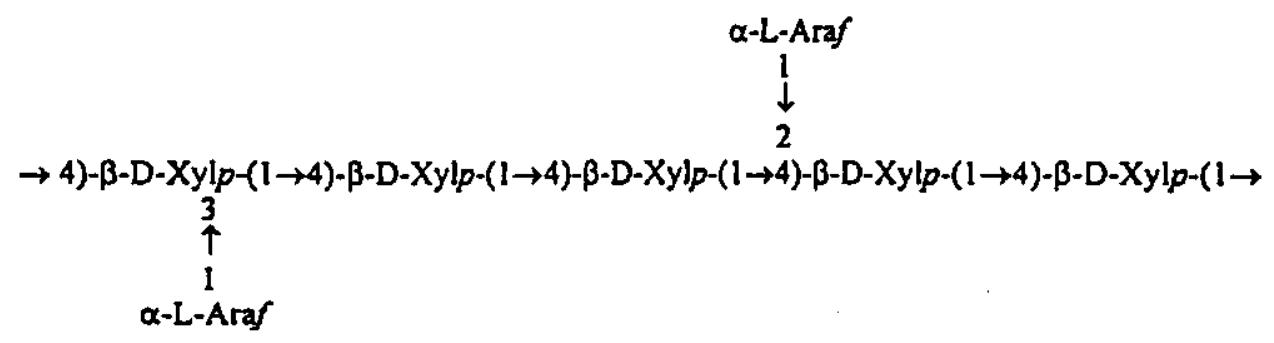

Figure 4. Fragment of arabinoxylan which occurs as part of the hemicellulose group

wall. The hemicelluloses/xylans bind to the surface of cellulose microfibrils and to each other, creating a coating that helps to bind the fibrils together into a complex network (Figurc 1).

Xyloglucans have a ccllulose-like backbone of $\beta$-D-Glc $p$ units linked by 1-4 bonds, heavily substituted with $\alpha$-D-Xyl $p$ which can be further substituted (Figure 5) with mainly $\beta$-D-dGal $p$ and $\alpha$-L-Fuc $p$ (Selvendran, 1983; Stephen, 1983; Fry, 1988; Bretl and Waldron, 1990). Such compounds occur in hulls from rape seed (Aspinall et al., 1977), and xyloglucans may account for ca. $20 \%$ of the primary cell wall in dicots, whereas they are mostly absent from secondary cell walls (Figure 1), except for some specialized storage cell walls of some species (Fry, 1988).

A special feature with some xyloglucans is their ability to give blue colours with $\mathrm{I}_{3}^{-} \mathrm{K}^{+}$solutions corresponding to the amyloid properties of starch.

Galactomannans which are another group of hemicellulose constituents, are known to occur widely in musilages e.g. in seed of Leguminosae (Dea and Morrison, 1975). The usual structure consists of 1-4 linked chains of $\beta$-D-Man $p$

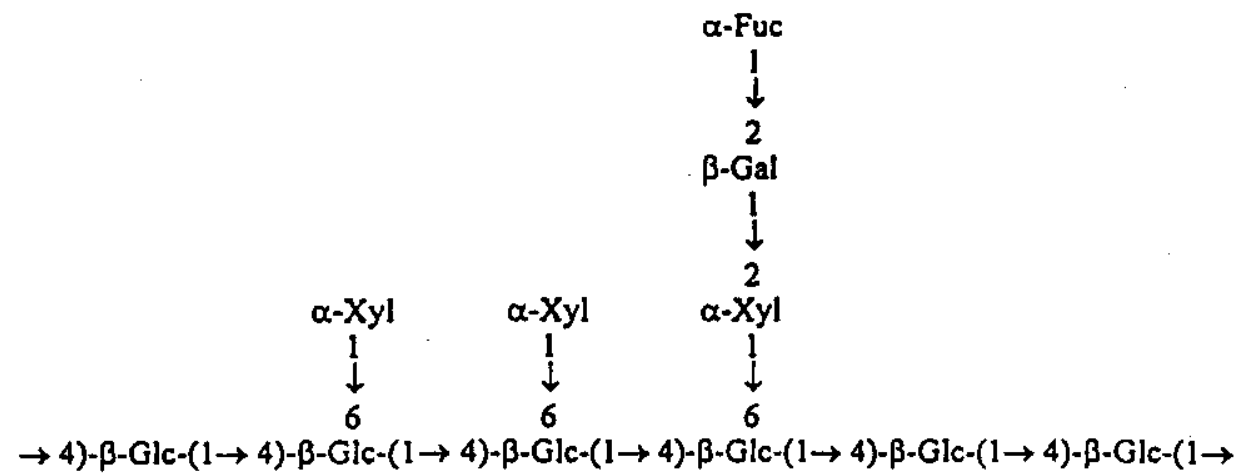

Figure 5. Fragment of xyloglucan which occur as part of the hemicellulose group 
units to which varying portions of $\alpha-\mathrm{D}-\mathrm{Gal} p$ groups are attached at C-6. Glucomannans are linear polymers of $\beta$-D-Glc $p$ and $\beta$-D-Man $p$ units linked by $1-4$ bonds, and these compounds occur mainly in the secondary cell wall. The proportion of the two sugar residues varies very much, covering a range from close to $100 \%$ Glc to nearly $100 \%$ Man in the unusual mannans. Side groups of $\alpha$-D-Galp occur to varying extent, leading to galactoglucomannans. These properties may be involved in the non-covalent binding of $\alpha$-galactosides/oligosaccharides to pea DF (Arentoft and Sørensen, 1992) as appreciable amounts of galactomannans and galactoglucomannans have been found in many legume species (Stephen, 1983).

\section{Cell wall or DF associated proteins-glycoproteins}

Cell walls or DF contain appreciable amounts of proteins as glycoproteins and enzymes e.g. myrosinase in rape seed DF (Bjergegaard and Sørensen, 1995). The total amount of protein in DF may account for $10-30 \%$ or some time even more of the total DF mass, with appreciable differences found as function of the DF source, c.g. tenerally relative low levels in pea DF and high levels in rape seed DF (Bjergegaard et al., 1991a, b; Bjergegaard and Sørensen, 1992; Danielsen et al., 1994). Prominent among the cell wall glycoproteins is a group of related compounds called extensins. These proteins resemble collagens with respect to their high content of hydroxyproline, and they are thought to form crosslinked networks with each other as well as with cellulose microfibrils, generating a reinforced protein-polysaccharide complex (Figure 1).

With the present knowledge, DF- or cell wall proteins can be classified into;

1. structural proteins

- arabinogalactan proteins (AGPs)

- hydroxyproline rich glycoproteins (HRGPs)

- proline rich proteins (PRPs)

- glycine rich proteins (GRPs)

2. lectins

3. enzymes

Group (1) glycoproteins are most often quantitatively dominating (Fry, 1988; Showalter, 1993). Intracellular glycoproteins are thus real DF constituents, and this can explain their resistance toward mammalian produced hydrolases or their resistance can be due to binding of the proteins to DF components after rupture of the cells (Bjergegaard et al., 1991 a,b; 1995 a; Eggum et al, 1993; Danielsen et al., 1994; Michaelsen et al., 1994). According to Lamport (1980) a range of membrane proteins and proteins located in the cytosol (Figure 1) are in fact glycosylated which make them more resistant to proteascs. This can be part of the explanation to the relatively low protein digestibility (TD-values) well known 
for the otherwise high quality rape seed proteins (Bille et al., 1983; Danielsen et al., 1994). A nutritional advantage of DF can also be their ability to bind lectins in food or feed, reducing the nutritionally disadvantage of lectins, which otherwise may be damaging the villi in the small intestine.

Extensins, which were the first group of structural cell wall proteins described, are rich in hydroxyproline (Hyp) and Ser (hydroxyproline rich glycoproteins; HRGPs) and relatively rich in Val, Tyr, Lys and His. These HRGPs are usually characterized by frequent scquences of Ser-(Hyp $)_{4}$ in the polypeptide chain, where arabinans or Type $I I$ arabinogalactans are bound as $\beta$-glycosides to the hydroxygroup in Hyp (see the section on pectins; vide supra). The carbohydrate parts account usually for up to $40-60 \%$ of these molecules (Fincher et al., 1983), and due to a high content of basic amino acids they have $\mathrm{pH}_{\mathrm{i}}$ of about 10-11 (Fry, 1988; Showalter, 1993). In rape seeds, a group of the storage proteins with such high $\mathrm{pH}_{\mathrm{i}}$ are known as napins (Bjergegaard et al., 1995 b,c,d).

The primary cell wall (Figure 1) of dicots contains often $1-10 \%$ extensins, whereas these proteins seem to be absent from the secondary cell walls (Fry, 1988), and specific extensins occur in different tissues and cell types (Keller, 1993). Isodityrosine has thus been found in extensins linking two molecules together (Cassab and Varner, 1988), and other propose intramolecular binding in extensins as a result of a Tyr-Lys bonds (Kieliszewski and Lamport, 1994). These structures reduce the solubilities of extensins which can lead to a need for salt e.g. $\mathrm{CaCl}_{2}$ containing solvents or oxidizing agents like $\mathrm{NaClO}_{2}$ for the protein extraction (Fry, 1988).

Other structural proteins of the plant cell wall include the proline rich proteins (PRPs) and the glycine rich proteins (GRPs). These groups were not discovered until the 1980s and they are less well known than the extensins. GRPs are unglycosylated whilc PRPs may contain $0-20 \%$ carbohydratc. GRPs have frequent Gly-X sequences in which X often is Gly too. Total Gly content may reach 70\% (Showalter, 1993). PRPs have frequent Pro-Pro sequences and contain most often Hyp. Other amino acids found in the PRPs are Val, Tyr and Lys resulting in basic proteins. Like extensins both GRPs and PRPs are probably insolubilized in the wall over time, but the knowledge to these proteins is still insufficient (Showalter, 1993).

Arabinogalactan-proteins (AGPs) are proteoglycans with peptide chains making up only $2-10 \%$ of the moleculc (Fincher ct al., 1983). The polypeptide moiety is rich in Hyp, Ser, and Ala. Most Hyp residues are linked to polysaccharide composed as arabinogalactans (Showalter, 1993). The polypeptide moiety is protected against enzymatic hydrolysis, probably by the large polysaccharide moiety (Fincher et al., 1983). The carbohydrate part increases also the water solubility and extractability of AGPs are very high. In addition, AGPs have $\mathrm{pH}_{\mathrm{i}}$ values of approximately 1.5 due to the high content of uronic 
acids (Fry, 1988). The high water extractability indicates that AGPs are not covalently bound in the cell wall. Fincher et al. (1983) mention also that flavonol glycosides may bind to AGPs, and such compounds extracted from DF can efficiently be determined by micellar electrokinetic capillary chromatography (MECC) (Bjergegaard et al., 1993).

\section{Lignins, lignans and other phenolics in DF or plant cell walls}

Lignins are a group of polymerised aromatic alcohols formed in the cell wall structures from esterbound phenolic carboxylic acids. The phenolic carboxylic acids are cinnamic acid derivatives; $p$-coumaric-, ferulic-, and or sinapic acids, which are attached through esterbonds to the glycans (Mueller-Harvey et al., 1986; Fry, 1988) as mentioned in the hemicellulose section (vide supra). These hydroxycinnamic acids are mainly ferulic acid and coumaric acid in cereals and legume cell walls/DF (Hartley, 1972; Besle et al., 1994), whereas sinapic acid are quantitativley dominating in crucifers as e.g. rape seed (Kozlowska et al., 1990), and for all of the cinnamic acids with the transisomer highly dominant, as revealed from e.g. MECC analyses (Bjergegaard et al., 1992).

In addition, a number of hydroxycinnamic acid dimers (lignans) are formed, of which at least some cross link cell wall polymers (Besle et al., 1994). The cinnamic acid derivatives are in addition to forming ester bond to glycans also found to be ether-linked to lignin surfaces (Iiyama et al., 1994). The reduction of the carboxylic acids group to the alcohol groups present in lignins occur most likely with starting points from the ester groups, and such reactions need to be coupled with oxidations of other groups which could be formation of uronic acids from alcohols. The results of the polymerisation are ether and C-C bonds (Figure 6) and a strong, hydrophobic, irregular polymer (Brett and Waldron, 1990; Theander et al., 1993). The lignins are expected to vary in their actual structures as function of the plant and its cinnamic acid derivatives. This gives thus different types of lignin molecules which are predominant between the cellulose fibrils (Figure 1), where they have functions as resistance of the cell walls against compression forces, and they are of course also important factors in relation to the properties of DF (Slevendran, 1983; Theander and Åman, 1986; Grenet and Besle, 1991). The amount of lignin in the cell walls increases with the age of the plants. The start of lignin formation is in the middle lamella (Figure 1), and continues in the secondary cell wall (Grenet and Besle, 1991; Jung and Allen, 1995). The last developed glycans in the secondary cell walls do not contain lignin, whereas the middle lamella and the primary cell wall contain the majority of the total lignin content present in the cell walls (Brett and Waldron, 1990; Giger-Reverdin, 1995; Jung and Allen, 1995), which can be up to $25 \%$ of the dry weight in woody plants. 


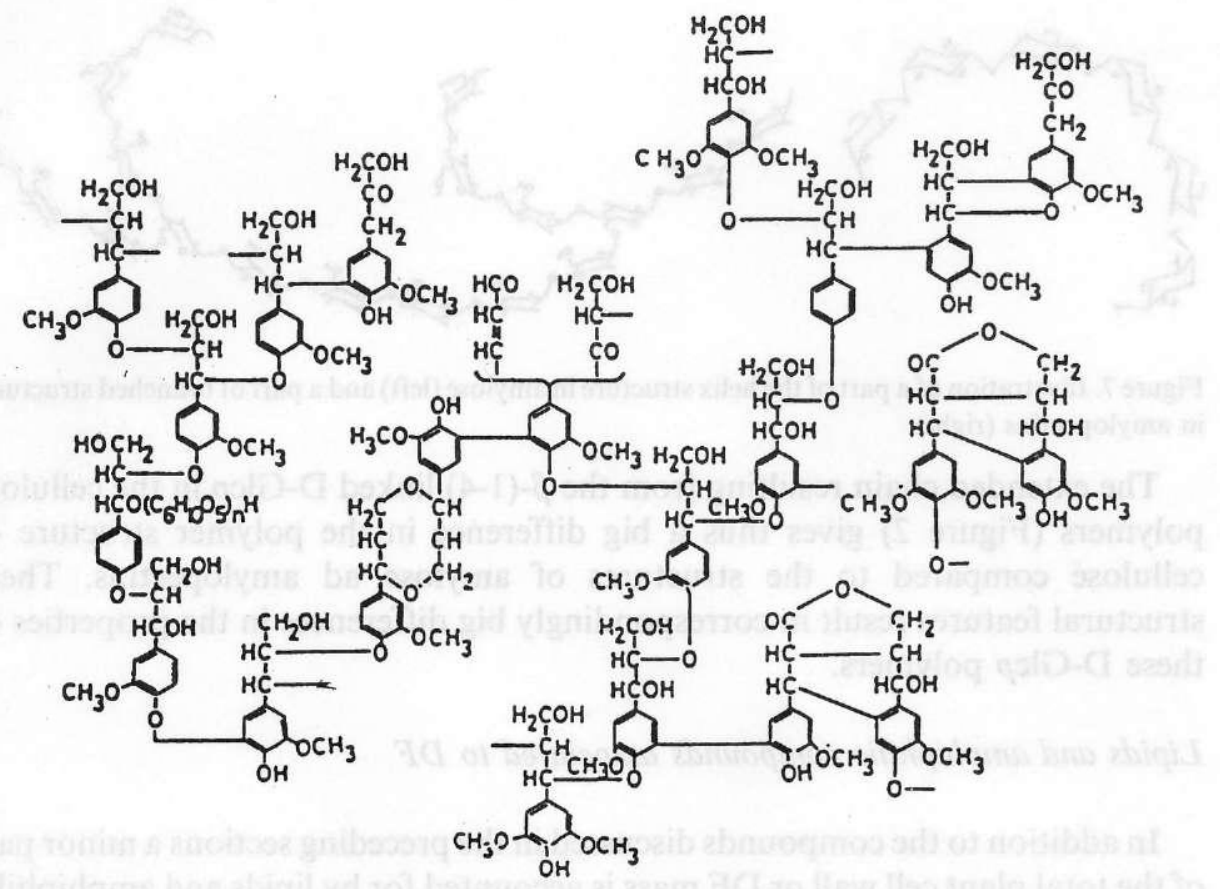

Figure 6. A proposal for part of a cruciferous rape seed lignin molecule with a relatively high content of sinapyl units

\section{Resistant starch}

Parts of the starch in some plant food or feed can be found in association with or as part of DF, and it is known as resistant starch (Asp et al., 1987; Galliard, 1987; Johnson and Southgate, 1996). The reason for the occurrence of undigestible starch can either be $\alpha$-amylase inhibitors (Yamaguchi et al., 1992; Zawistowska et al., 1992; Garcia-Casado et al., 1994; Masojc et al., 1994) in the diets, or it can be a result of binding of starch to DF cell walls caused by special features connected with the structure of starch, its amylose and amylopectins.

The configuration of the energetically favoured D-glucopyranose linked by $\alpha-(1-4)$ glucoside bonds result in helix structures of the linear amylose polymers (Figure 7). In amylopectins additional branching originating from $\alpha-(1-6)$ glucoside bonds give a much more complex structure for these polymers (Figure 7). The helix structures give the amyloid properties of amylose, e.g. the possibility of binding $\mathrm{I}_{3}^{-}$in the helix for each about six D-Glc $\mathrm{p}$ units resulting in blue coloured complexes. This is a typical property of amylose, but amylopectins will also, although to a much less extent, give such colour reaction which can be utilized in analytical procedures (Bjergegaard et al., 1997). 


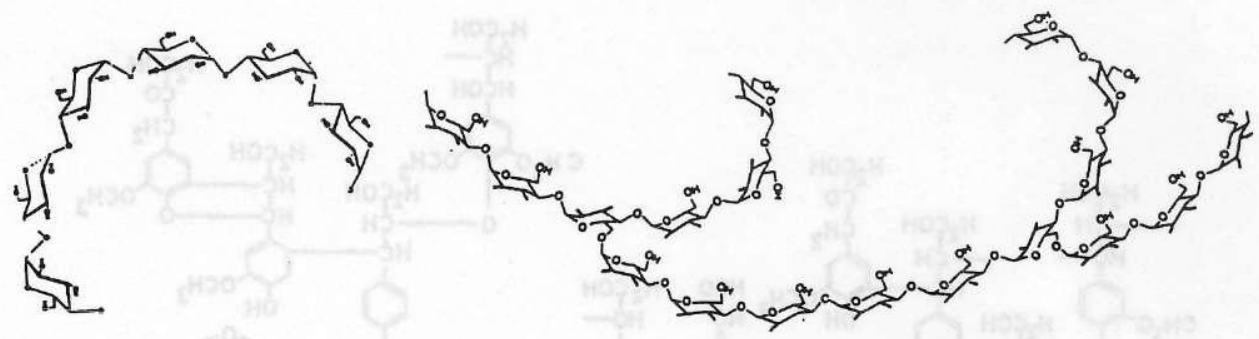

Figure 7. Illustration of a part of the helix structure in amylose (left) and a part of branched structures in amylopectins (right)

The extended chain resulting from the $\beta$-(1-4) linked D-Glc $p$ in the cellulose polymers (Figure 2) gives thus a big difference in the polymer structure of cellulose compared to the structures of amylose ad amylopectins. These structural features result in correspondingly big differences in the properties of these D-Glc $p$ polymers.

\section{Lipids and amphiphilic compounds associated to DF}

In addition to the compounds discussed in the preceding sections a minor part of the total plant cell wall or DF mass is accounted for by lipids and amphiphilic compounds. These hydrophobic molecules tend to be found on the external surface of the cell walls, where they may form a layer that protects the cells against injury and desiccation. Compounds of these types contribute also to the differences which occur among DF from different sources. DF from rape seed is thus able to bind lipids to a much greater extent than DF from pea, and such a binding of lipids can be a part of the explanation to the lower digestibility of energy in rape seed based feed (Bjergegaard et al., 1991 a, b; Danielsen et al., 1994; Bjergegaard et al., 1995 a-d). Minerals such as calcium and other di- or trivalent minerals as well as potassium and other monovalent minerals occur also in plant cell walls, predominantly in connection with pectins. This seems to be a result of DFs ability to specific binding of minerals (Bjergegaard et al., 1991b, 1994) which affect the availability of minerals in food and feed containing various types of $\mathrm{DF}$.

\section{CONCLUSION}

Dietary fibres (DF) are food and feed constituents resistant to degradation catalyzed by enzymes, especially hydrolases produced in mammalian cells. DF are mainly plant cell wall constituents and a quantitatively important part of plant based food and feed. 
DF are quantitatively dominated by non-starch polysaccharides, structural proteins and phenolics /lignin, but contain also other proteins and phenolics associated.

DF vary in composition and thercby also in constitution, structure and properties as function of DF source and of processing or treatment of the DF source/plant material.

DF from rape seed (crucifers) have much stronger binding of protein and lipids than DF from pea (legumes).

DF are important parts of high quality food and feed contributing with both positive physiological effects (binding of xenobiotica, ANC, lectins) and negative physiological effects (binding of macronutrients (proteins and lipids) and micronutrients (essential nutrients, vitamins)), which depend on the DF type or constitution.

Focus on DF research and DF methods of analyses should be placed not only on determination of the amount but especially on the type of DF, composition and constitution of DF, their binding properties and physiological effects.

\section{ACKNOWLEDGEMENTS}

The authors gratefully acknowledge financial support from EU, DGXII (CIPA-CT 93-0249) and from the Danish Ministry of Agriculture.

\section{REFERENCES}

Arentoft A.M., Sørensen H., 1992. $x$-Galactosides and dietary fibres in relation to pea quality; Methods of oligosaccharide analysis. Proccedings of 1st European Conference on Grain Legumes, Angers (France), 457-459

Asp N.G., 1987. Dietary fiber - delination, chemistry and analytical determination. Mol. Aspects Mcd. 9, 17-19

Aspinall G.O., Cottrell I.W., 1971. Polysaccharides of soybeans. VI. Neutral polysaccharides from cotyledon meal. Can. J. Chem. 49, 1019-1022

Aspinall G.O., Krishnamurthy T.N., Rossell K.G., 1977. A fucogalactoxyloglucan from rape seed hulls. Carbohyd. Res. 55, 11-19

Besle J.-M., Cornu A., Jouany J.-P., 1994. Roles of structural phenylpropanoids in forage cell wall digestion. J. Sci. Food $\Lambda$ gric. 64, 171-190

Bille N., Eggum B.O., Jacobsen 1.. Olsen O., Sørensen H., 1983. The effects of processing on antinutritional rape constituents and the nutritive value of double low rape seed meal. Z. Tierphysiol., Tierernähr.. Futtermittelk. 49, 148-163

Bjergegaard C., Eggum B.O., Jensen S.K., Sørensen H., 199la. Dietary fibres in oilseed rape: Physiological and antinutritional effects in rats of isolated IDF and SDF added to a standard diet (1). J. Anim. Physiol. Anim. Nutr. 66, 69-79 
Bjergegaard C., Jensen S.K., Sørensen H., 1991b. Dietary fibres in oilseed rape: Properties and effects on the digestibility of rape seed meal. GCIRC - Congress, Saskatoon (Canada), II, 448-453

Bjergegaard C., Sørensen H., 1992. Biochemical - physiological properties of dietary fibres (DF) in pea compared to the properties of DF from other plants. Proccedings of 1st European Conference on Grain Legumes, Angers (France), 459-461

Bjergegaard C., Michaelsen S., Sørensen H., 1992. Determination of phenolic carboxylic acids by micellar electrokinetic capillary chromatography and evaluation of factor affecting this method. J. Chromatogr. 608, 403-411

Bjergegaard C., Michaelsen S., Mortensen K., Sørensen H., 1993. Determination of flavonoids by micellar electrokinetic capillary chromatography. J. Chromatogr. 652, 477.485

Bjergegaard C., Fisker H.J., Hansen L.M.. Johannsen A.K.B., Sørensen H., 1994. In vitro binding capacities of dietary fibres from rape seed and peas toward tryptophan, water and minerals. The International Conference on Dietary Fibres. Mechanisms of Action in Human Physiology and Metabolism, Nantes (France)

Bjergegaard C., Sørensen H., 1995. Characterization of proteins, including myrosinases associated to rape sced dictary fibres, compared to proteins in pea dictary fibres. Polish J. Food Nutr. Sci. $4(45), 47-57$

Bjergegaard C., Ingvardsen L., Sørensen II., 1995a. Processing of oilseed rape using the enzyme based technique and a simple step to removal of minor parts of the dietary fibres result in appreciable increased digestibility of rape seed protein and energy. Bulletin - GCIRC, 11, $120-130$

Bjergegaard C., Ochodzki P., Rakowska M., Sørensen II., 1995b. Studies on enzyme based fractionation, chemical composition and biological effects of dietary fibres in rape seed (Brassica napus L.). 1. Chemical composition of seeds and characteristics of soluble and insoluble dietary fibres of spring and winter type varieties of double low oilseed rape. J. Anim. Fced Sci. 4, 127-138

Bjergegaard C., Ochodzki P., Rakowska M., Rek-Cieply B., Sørensen H., 1995c. Studies on enzyme based fractionation, chemical composition and biological effects of dietary fibres in rape seed (Brassica napus L.). II. Influence of rape seed dietary fibres on protein and organic matter digestibility in rats, using unprocessed and heated full fat rape seed and isolated dietary fibre fractions added to rat diets. J. Anim. Feed Sci. 4, 139-151

Bjergegaard C., Ochodzki P., Rakowska M., Rek-Cieply B., Sørensen H., 1995d. Studies on enzyme based fractionation, chemical composition and biological effects of dietary fibres in rape seed (Brassica napus L.). lll. Degradation of the dietary fibre compounds of rape secd by microbial enzymes and its influence on nutrient utilization by rats and chicken. J. Anim. Feed Sci. 4, 153-160

Bjergegaard C., Sørensen II., 1996. Antinutritional compounds in feed and food. In: Proceedings of $4^{\text {th }}$ International Feed Production Conference, Piacenza (Italy), $29 \mathrm{pp}$.

Bjergegaard C., Sørensen H., Sørensen S., 1997. Dictary fibres and associated compounds in rape seed and biorefined rape seed products compared to DF in pea. J. Anim. Feed Sci. 6, 163-184

Brett, C., Waldron K., 1990. Cell wall structure and the skeletal functions of the wall. In: Physiology and biochemistry of plant cell walls. Unwin Hyman, London, $194 \mathrm{pp}$.

Cassab G.I., Varner J.E., 1988. Cell wall proteins. Ann. Rev. Plant physiol. Plant Mol. Biol. 39, $321-353$

COST 92, 1995. Metabolic and physiological aspects of dietary fibre in food. Recent progress in the analysis of dietary fibre. Proceeding of a Workshop, Copenhagen (Vedbæk) (Denmark), 28-29 October 1994. Published by EU, Directorate-General XII, Science, Research and Development, L-2920 Luxembourg

Danielsen V., Eggum B.O., Jensen S.K., Sørensen II., 1994. Dehulled protein-rich rape seed meal as protein source for early weaned piglets. Anim. Feed Sci. Techol. 46, 239-250 
Dea I.C.M., Morrison A., 1975. Chemistry and interactions of seed galactomannans. Advan. Carbohyd. Chem. Biochem. 31, 241-321.

Dreher M.L., 1987. Conventional and unconventional dietary fiber components. In: Handbook of dictary liber, an applied approach. Marcel Dekker Inc., New York/Basel, pp. 17-49

Eggum B.O.. Jensen S.K., Sørensen II., 1993. The nutritive value of dehulled protein rich rape seed meal produced by aqueous enzymatic extraction. GCIRC Bulletin 9, 37-41

Esau K., 1977. Cell wall. In: Anatomy of Seed Plants. John Wilcy and Sons Inc., Ncw York/Chichester/Brisbane/Toronto/Singapore, pp. 43-60

Fincher G.B., Stone B.A., Clarke A.E., 1983. Arabionogalactan-proteins. Structure, biosynthesis, and function. Ann. Rev. Plant Physiol. 34, 47-70

Fry S.C., 1988. The Growing Plant Cell Wall. Chemical and Metabolic Analysis. Longman Scientific and Technical, Harlow, UK, 333 pp.

Furda I., Brine C.J., 1990. New developments in dietary fibre. Physiological, physicochemical and analytical aspects. In: Advances in experimental medicine and biology Vol. 270. Plenum Press, New York

Galliard T., 1987. Starch availability and utilization. In: T. Galliard (Editor). Starch: properties and potential. John Wilcy and Sons, pp. 1-15

Garica-Casado G., Sánchez-Monge R., López-Otín, Salcedo G., 1994. Rye inhibitors of animal $x$-amylases show different specilicities, aggregative propertics and IgF-binding capacitics than their homologues from wheat and barley. Eur. J. Biochem. 224, 525-531

Giger-Reverdin S., 1995. Review of the main methods of cell wall cstimation: interest and limits for ruminants. Anim. Feed Sci. Technol. 55, 295-334

Grenet E., Besle J.M., 1991. Microbes and libre degradation. In: Rumen microbial metabolism and ruminant digestion. J.-P. Jouany (Editor). INRA Editions, Paris

Hartley R.D., 1972. p-Coumaric and ferulic acid components of cell walls of ryegrass and their relationships with lignin and digestibility. J. Sci. Food Agric. 23, 1347-1354

liyama K., Lam T.B., Stone B.A., 1994. Covalent cross-links in the cell wall. Plant Physiol. 104, 315-320

Johnson I.T., Southgate D.A.T., 1996. An introduction to the dietary fibre hypothesis. In: Dictary fibre and related substances. Chapman and Fall, pp. 10-38

Jung H.G., Allen M.S., 1995. Characterization of plant cell walls affecting intake and digestibility of forages by ruminants. J. Anim. Sci. 73, 2774-2790

Keller B., 1993. Structural cell wall proteins. Plant Physiol. 101, 1127-1130

Kieliszewski J.J., Lamport D.T.A., 1994. Fxtensin: repetitive motifs, functional sites, posttranslational codes, and phylogeny. Plant J. 5, 157.172

Kozłowska H., Naczk M., Shahidi F., Zadernowski R. 1990. Phenolic acids and tannins in rape seed and canola. In: Canola and rape seed. Production, chemistry, nutrition and processing technology. F. Shahidi (Editor). Van Nostrand Reinhold, New York, pp. 193-210

Lamport D.I.A., 1980. Structure and function of plant glycoproteins. In: J. Preiss (Editor). The biochemistry of plants, a comprehensive treatise. Vol. 3. Academic Press, New York, pp. $501-541$

Masojc P., Zawistowski J., Za wistowski U., 1994. Polymorphism of cndogenous $x$-amylase inhibitor in barley. J. Cereal Sci. 20, 43-49

Michaelsen S., Otte J., Simonsen L.O., Sørensen H., 1994. Absorption and degradation of individual intatel glucosinolates in the digestive tract of rodents. Acta Agric. Scand., Sect. A. 44, 25-37

Moore K.J., IIatfield R.D., 1994. Carbohydrates and Forage Quality. In: G.C. Fahcy (Editor). Forage quality, evaluation, and utilization, pp. 229-28I

Mueller-Harvey I., Harley R.D., Harris P.J., Curzon E.Il., 1986. Linkage of p-coumaroyl and feruloyl groups to cell wall polysaccharides of barley straw. Carbohyd. Res. 148, 71-85 
O'Neill M., Albersheim P., Carvill A., 1990. The pectic polysaccharides of primary cell walls. In: Methods in plant biochemistry, Vol. 2. Carbohydrates. P.M. Dey (Editor). P.M. Dey, J.B. Harborne (Series Editors). Academic Press, London, pp. 415-441

Selvendran R.R., 1983. The chemistry of plant cell walls. In: G.G. Birch, K.J. Parker (Editors).

Dietary fibre. Applied Science Publisher, London/New York, pp. 95-147

Showalter A.M., 1993. Structure and function of plant cell wall proteins. Plant Cell. 5, 9-23.

Siddiqui I.R., Wood P.J., 1977. Carbohydrates of rape seed: $\Lambda$ review. J. Sci. Food $\Lambda$ gric. 28, 530-538 Stephen A.M., 1983. Other plant polysaccharides. In: G.O. Aspinall (Editor). The polysaceharides, Vol. 2. Academic Press, Inc., Orlando, pp. 97-193

Theander O., Åman P., 1979. The chemistry, morphology and analysis of dietary fiber components. In: G.E. Inglett, S.I. Falkehag, (Editors). Dietary fibers: Chemistry and nutrition. Academic Press Inc., New York/San Francisco/London, pp. 215-228

Theander O., Åman P., 1986. Anatomical and Chemical Characteristics. In: F. Sundstøl, E. Owen (Editors). Straw and other fibrous by-products as feed. Elsevier, Developments in Animal and Veterinary Sciences, 14

Theander O., Westerlund E., Åman P., 1993. Structure and components of dietary fiber. Cereal Food World. 38, 135-14l

Waldron K.W., Johnson I.T., Fenwick G.R., 1993. Food and Cancer Prevention: Chemical and Biological Aspects. Part 7. Dietary Fibre and Related Substances. The Royal Society of Chemistry, Thomas Graham House, Science Park, Cambridge CB4 4WF, UK, pp. 339-380 Yamaguchi H., Funaoka H., Iwanoto H., 1992. Structures of sugar chains of the subunits of an $\alpha$-amylase inhibitor from Phaseolus vulgaris white kidney beans. J. Biochem. 111, 388-395

Zawistowska U., Zawistowska J., Friesen A.D., 1992. Application of immobilized metal affinity chromatography for large-scale purification of endogenous $\alpha$-amylase inhibitor from barley kernels. Biotech. Appl. Biochem. 15, 160-170

\section{STRESZCZENIE}

\section{Wlókno pokarmowe - ważny skladnik pasz i wartościowej żywności}

Whókno pokarmowe (DF) jest to materiał roślinny lub składniki ścian komórek roślinnych odporne na hydrolizę przez enzymy wydzielane przez komórki górnej części przewodu pokarmowego ssaków. W pracy omówiono fizjologične driałanie DF, jego wpływ na składniki odżywcze i nie mające wartości odżywczej, w tym ksenobiotyki, wpływ na konsystencję i skład treści pokarmowej oraz na mikrofiorę przewodu pokarmowego. Korzystny lub niekorzystny wpływ DF na jakość żywności i paszy zalcży od rodzaju włókna, a ponicważ DF jest niezbędnym i ważnym składnikicm wszystkich wartościowych produktów spożywczych i pasz, należy więcej uwagi poświęcić jego strukturze.

Sklad chemic/ny i budowa DF oraz jego właściwości fizyko-chemiczne i działanie fizjologiczne sa obecnie przedmiotem rosnącego zainteresowania. W związku z tym szczególną uwage poświęciliśmy wszystkim składnikom DF, nic tylko węglowodanom, alc wszystkim związkom, od których zalcżą wlaściwości wiązania przez DF sk̉ładników odżywczych, a także nie mających warlości odjywczej. W wyniku badań prowadzonych na wyizolowanym DF powstało nierozwiązane dotychczas zagadnienie czy działanie wlókna wydzielonego z matrycy paszy lub żywności różni się od działania 
włókna strukturalnego (natywnego). W badaniach nad wlóknem powinna być zawšc uwzględniona budowá i właściwości DF. Badania takie muszą opierać się na metodach analitycznych i powinny dostarczyć informacji, uwzglẹdniając następujące czynniki: 1. skład; rodzaj wẹglowodanów, tłuszczów, białck, związków fenolowych i innych składników DF; 2. budowa; struktura DF' i jego skladników; 3. konliguracja; stercochemia DF i jego składników; 4. budowa przestrzenna; faktyczna lub preferowana budowa przestrzenna rozpuszczonego DF.

W systematycznych badaniach nad DF powinna być zachowana kolejność od 1 do 4; trzy ostatnie grupy informacji pozwalaja zrozumieć właściwości wiązania i fizjologiczne działanie DF. 